\title{
自動感度可変型触覚センサ
}

$\bullet$

堀 江 竜 太* 金子 真*

\section{A Sensitivity Variable Tactile Sensor with Self-Tuner}

\author{
Ryuta Horie* and Makoto Kaneko*
}

\begin{abstract}
This paper proposes a tactile sensor capable of automatically adjusting its sensitivity, depending upon the contact information. Suppose a strain gauge based sensor, such as multi-axis force sensor and tactile sensor. One big issue for those sensors is the signal saturation due to large input for a particular direction. The proposed sensor system can automatically avoid such a situation with combination of Automatic Gain Control (AGC). The sensor is composed of a controller and an analyzer. The analyzer provides with the contact force and the controller tunes up the amplitude of each frequency. We discuss the basic design relue where two theorems are introduced for guaranteeing the working principle of the sensor with AGC. Experimental results are also shown for validating the basic idea of the proposed sensor.
\end{abstract}

Key Words: Tactile Sensor, Automatic Gain Control, AGC, Filter

\section{1.は じめに}

ヒトの皮虐には 1 平方センチ当たり, 約 1,500 のマイスナー小 体, 約 750 のメルケル触覚盤, 約 75 のパシニアン小体, ルフィ 二器官といった多数の触覚受容器が表層から深部にかけて存在 し, これらの時間応答や空間応答の異なる触覚受容器によって, 軽く触れた触覚から衝撃力まで幅広い計測レンジを実現してい る.一方, これまでに研究開発されてきた触覚センサや力覚セ ンサは，七ンサの感度を自由に制御することができず，ヒトの 皮膚のように幅の広いダイナミックレンジを実現することは困 難であった。 そのため, 規定をオーバーする強い印加力に対し ては, センサの出力がたちまち飽和したり, 逆に極端に小さな 印加力に対しては分解能が悪くなるといった問題が生じていた。 このような問題に対応するため, 本研究ではFig. 1 のようなセ ンサ入力に応じてゲインを適切に調節することが可能な自動利 得制御 (Automatic Gain Control:AGC) 機能を備えた歪ゲー ジ式の触覚センサを提案し，七ンサの基本的な設計方針につい て考察することを目的としている.ただし，Fig. 1 (a)はアンプ のゲインを直接変える方法で, Fig. 1 (b) はセンサ素子のドライ ブ電源つまりブリッジ電源を変えて等価的にゲインを変える方 法である. AGCの考え方はすでにCCDカメラやマイクのアン プ等で実装さ机ており, 規定を超えた強いレベルの信号が入力 されたときや微弱信号に対しては出力を一定範井内に保てるよ うになっている。しかし，これらは基本的に出力を一定に保つ

原稿受付 2002 年 11 月 8 日

*広島大学大学院工学研究科

* Graduate School of Engineering, Hiroshima University

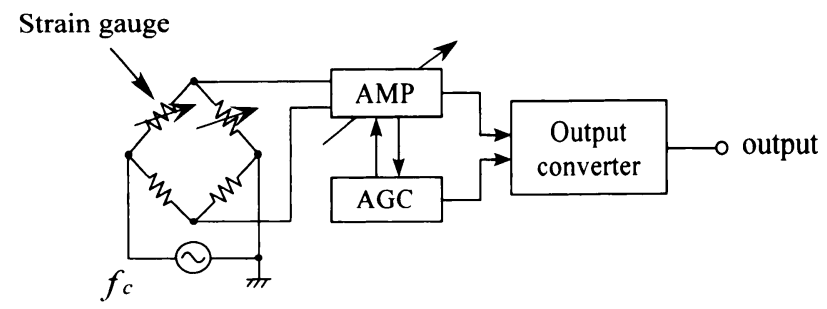

(a) A varliable amplifier system

Strain gauge

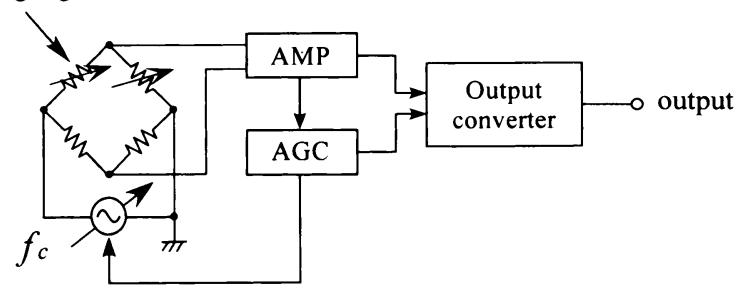

(b) A variable bridge power supply system

Fig. 1 Tactile sensor systems with AGC

ように制御されているだけで，増幅された信号とゲインを一対 一に対応づけて入力信号を計測している訳ではない. 入力信号 をフィードバックループ内で計測する場合，入力信号の周波数， AGCのスイッチング周波数, フィルタの周波数特性等に十分留 意する必要がある。ここで, Fig. 1 (a)，(b)は共にセンサ出力に 応じてゲイン調節を行う AGCと，増幅された信号とゲインを 一対一に対応づける変換器を有する。このようなフィードバッ クループを構成することで原理的にはゲインを自動調節し, ダ 
イナミックレンジを広くすることができる反面，周波数特性に ついて十分考慮しなけ机ばセンサとしてうまく動作しない。本 論文ではブリッジ電源に交流を用いる交流電源方式の歪ゲージ 式触覚センサに着目し, $\mathrm{AGC}$ 機能を備えた触覚センサが適切に 動作するための条件を:つの定理としてまとめる．定理 1 では 有限の周波数を仪定した場合に, 入力信号の周波数と $\mathrm{AGC}$ の スイッチング周波数の満足する条件をまとめ, 定理 2 ではゲイ ンをステップ状に変化させたときに，尘理 1 を緩和する垁用的 手法について整理している，実験では，定理 2 に基づいてコン トローラを設計し, 動作確認を行っている.

\section{2. 関 連 研 究}

ロボットにおける触覚センサの研究は, Ernst [1]らによって 1960 年頃から始まった。 その後, 感度や分解能, 線形性, 少配 線構造, 実装性など様々な角度から数多くの触覚センサが提案さ れてきた。従来， $M+N$ 本の配線を使った $M \times N$ のマトリッ クス構造の触覚センサ [2] [5]を, 各計測点に対して一つ一つ切 り替えて計測する方法が多くとら机てきた。このタイプの触覚 センサは, 共通の問題点として各計測点の情報を読み取るのに 多くの配線を必要とする.このような問題点に対し, フィル夕の 特性を利用して配線の量を減らすという観点からの研究 [6]一 [8] がある。また，近年 Shinoda [9] らにより柔軟な材質の中に多 くの共振回路を配置し、コイルを使って電力転送とセンシング を無線で行う触覚センサも提案されている.

本論文では, 歪ゲージ式の触覚センサにおいて，特に自動利 得制御（AGC）を備えた触覚センサについて考察する。これま で, 多くの触覚センサ [9] [17]が提案さ机ているものの, 筆者 らが知る範囲において AGC が可能な触覚センサは提案されて いないように思われる。

\section{3. センサの基本動作原理}

\section{1 基本構成}

価ゲージは機械的な微小变化量である霜を電気信号として検 出する素子で, 荷重や任力, 加速度, トルク, 変位などを測定 することができる。この歪ゲージは, Fig. 2(a)のような分布 型触覚センサや 6 軸力・モーメントセンサによく利用されてい る。こ机らのセンサは, 各センサ素子間のカップリングを考慮 しなけ札 Fig. 2 (b)のような試験片に歪ゲージを貼り付けたも のから構成されていると考えることができる. 以下, 議論を簡 単にするために, Fig. 2(b)を例にとって考察を行う。

ブリッジ回路の電源 $E$ は, 交流を用いる方式と直流を用い る方式がある。交流電源 $(\mathrm{AC})$ 方式は，ノイズやアンプのドリ フトなどに強いが, 動歪の測定では入力さ机る周波数よりもブ リッジ電源の周波数の方が高い必要があるために, 帛域で制限 を受ける。一方，直流電源 (DC) 方式は入力さ机る周波数は高 くとれるが, アンプのドリフトやノイズに弱いという久点を持 つ. 本論文では, 交流電源方式の奀ゲージ式触覚センサに着目 する.

\section{2 歪検出の原理}

接触力と歪ゲージの抵抗変化量 $\Delta R$ に線形性が成り立つと仮 定すれば, Fig. 2(b)においてブリッジ電源 $E$ に周波数 $f_{c}$ の

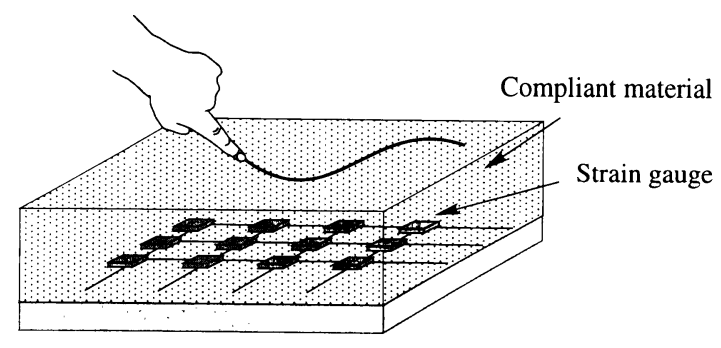

(a) Tactile array sensor

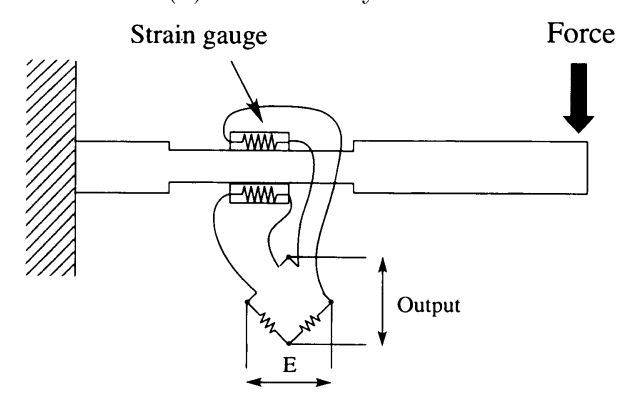

(b) Basic unit

Fig. 2 Examples of strain gauge based tactile sensors

正弦波を印加したときの差動電圧 $V(t)$ は，次式で表せる.

$$
V(t)=G \times \frac{\Delta R}{2 R} A \sin \left(2 \pi f_{c} t+\phi\right)
$$

ただし， $G, \phi, \Delta R, R$ はそれぞれ, 差動アンプのゲイン, 印加周 波数との位相のずれ, 接触力による歪みゲージの抵抗変化量, ブ リッジ回路のバランス抵抗を示す。この式は $(A / 2 R) \sin \left(2 \pi f_{c} t\right)$ を搬送波とし，接触力の情報を振幅变調（Amplitude Modulation：AM）したものと考えることができる。したがって，この 差動電圧 $V(t)$ から接触力を求めるためには, 検波 (復調) す る必要がある。検波の原理は次の通りである。ブリッジに印加 してある周波数（搬送波） $f_{c}$ は既知なので, 出力 $V(t)$ に対し て正弦波と余弦波との乗算を行う。

$$
\begin{aligned}
& V_{x}(t)=V(t) \times \sin \left(2 \pi f_{c} t\right) \\
& V_{y}(t)=V(t) \times \cos \left(2 \pi f_{c} t\right)
\end{aligned}
$$

ト式で得られた $V_{x}(t)$ と $V_{y}(t) に$ LPF（Low Pass Filter）を 通したものを $X(t), Y(t)$ とすると, 接触力扰よび位相は次の ように表せる。

$$
\begin{aligned}
|F(t)| & =d \sqrt{X^{2}(t)+Y^{2}(t)} \\
\text { Phase }(t) & =\arctan \frac{X(t)}{Y(t)}
\end{aligned}
$$

ただし，dはキャリブレーションによって電压を接触力に変換 する定数を示す。こ机ら一連の操作は，正弦波と余弦波との相 関を求めるフーリ工変換と等価な処理である. 式 (5) で得られ た位相情報P Phase(t)は，接触力の方向を表して扔り，符号の 変化によって押し付け力か引張り力かの判定を行うことができ る、ただし，触覚センサの場合，一般に押し付け力しか作用し ないため赛用上Phase $(t)$ を求める必要はない. 


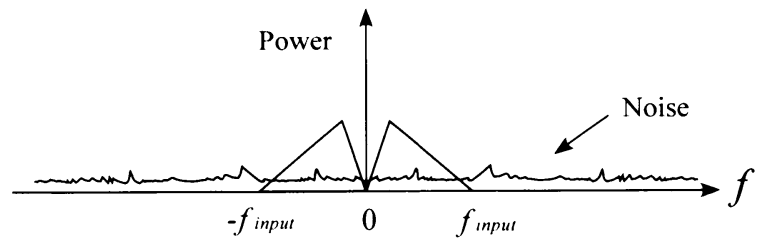

(a) Input signal band

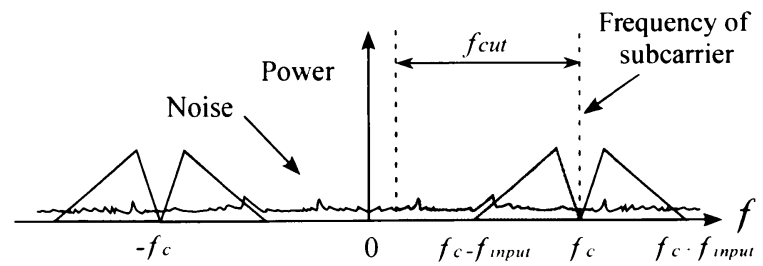

(b) The effect of the amplitude modulation

Fig. 3 The feature of amplitude modulation

\section{3 計測条件}

振幅変調を行うとFig. 3 (a) に示すような接触力のスペクトル は，搬送波の周波数 $f_{c}$ だけ移動してFig. 3(b)のようになる。た だし $f_{\text {input }}, f_{\text {cut }}$ はそれぞれ接触力の最大周波数, LPFのカッ トオフ周波数を示す. Fig. $3(\mathrm{~b})$ において周波数が $f_{c}-f_{\text {input }}$ から $f_{c}$ に相当する部分を LPFで切り取る操作が検波である。 このFig. 3(b)に示した関係より振幅変調を正しく行うには, 以 下の関係式を満たす必要がある。

$$
f_{\text {input }}<f_{\text {cut }}<f_{c}
$$

このことからセンサに印加する周波数よりもブリッジ電源の周 波数を高く設定する必要があり, 検出できる周波数は高域で制 限を受けることが分かる。また，振幅変調方式がノイズに蚛い 理由は, LPFのカットオフ周波数 $f_{c u t}$ 以外の带域がカットさ れるためである。

\section{AGC を備えた触覚センサの提案}

\section{1 AGC の構成}

$\mathrm{AGC}$ 機能を備えた触覚セン卅を構成する場合, $f_{\text {input }}, f_{\text {cut }}$, $f_{c}$ に加えてゲインの更新猿波数 $f_{s}$ を考慮してフィードバック 系を設計する必要がある。本章では AGC 機能を備えた触覚七 ンサが適切に動作するための条件について考察し, 二つの定理 を導入する.

本システムではFig. 4 に示すように以トのような操作によっ て，適応的に差動アンプのゲイン $G$ またはブリッジ電源の電庄: 振幅 $A$ を変化させる.

$$
\begin{aligned}
E(t) & =A_{r}(t)-A_{o}(t) \\
\Delta W(t) & =\alpha \int_{0}^{T} E(t) d t
\end{aligned}
$$

ただし， $A_{r}(t), A_{o}(t), E(t), \Delta W(t), \alpha$ はそれぞれ目標值 $(\mathrm{V})$, 出力值 $(\mathrm{V})$, 目標值との䛊差, ゲインまたはブリッジ電 源の修正量, 小さな正の定数を示す.式（8）は，積分によって 高周波をカットする効果を持たせ，頻繁に変化する䛊差をなだ
らかに変化させる意网がある。ここで，七ンサ出力が飽和する ということは, 式 (1) の $V(t)$ が $\mathrm{AD}$ 変換器やアンプの最大人 力電圧 $V_{\text {input } \mid \text { max }}$ を超えたときの状態である．センサ出力が飽 和しないためには，次式の条件を满たすようにゲイン制御を行 う必要がある。

$$
V(t)<V_{\text {input } \mid \text { ma.r }}
$$

式（1）において出力電压 $V(t)$ を変化させることができる変数 は， $G$ と $A$ の二つあることが分かる.つまり，Fig. 1 (a)のよ うにブリッジ電源の電圧振幅 $A$ は一定の状態で差動アンプのゲ イン $G$ を変える方法と, Fig. 1(b)のように差動アンプのゲイ ン $G$ は一定のままでブリッジ電源の電圧振幅 $A$ を変える方法 である。それぞ机のメリット，デメリット（付録 $\mathrm{A}$ を参照）が あるが，ここではブリッジ電源を直接変える方法を例にとって 説明する，後述する定理は，いず机の方式においても成り立つ ことを付記しておく.

\subsection{AGCの動作条件}

ここで，センサに印加する力 $f(t)$ とゲイン $g(t)$ が共に変化 する場合を考えてみよう。式（1）より接触力とゲインが時間領 域での積をなすので, $f(t) g(t)$ のスペクトルは次式のように周 波数領域における胃込み積分となる。

$$
\begin{aligned}
F T\{f(t) g(t)\}(f) & =\int_{-\infty}^{\infty} G\left(f_{1}\right) F\left(f-f_{1}\right) d f_{1} \\
& =G(f) * F(f)
\end{aligned}
$$

ただし $F T\{x(t)\}, F(f), G(f), *$ はそれぞれ $x(t)$ のフーリエ

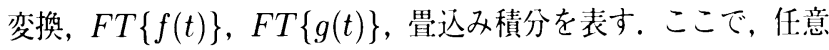
の関数がデル夕関数の和で近似できることから， $G(f)$ と $F(f)$ は次式のようなデル夕関数の和で表現することができる.

$$
\begin{aligned}
& G(f)=\sum_{i=1}^{N} a_{i}\left\{\delta\left(f-f_{i}^{\prime}\right)+\delta\left(f+f_{i}^{\prime}\right)\right\} \\
& F(f)=\sum_{j=1}^{M I} b_{j}\left\{\delta\left(f-f_{j}^{\prime \prime}\right)+\delta\left(f+f_{j}^{\prime \prime}\right)\right\}
\end{aligned}
$$

ただし， $a_{i} ， b_{j}$ はそれぞれ定数である. 式 (11)，(12) を式 （10）に代入すると毘込み積分は次のように展開することがで きる。

$$
\begin{aligned}
F(f) * G(f)= & \int_{-\infty}^{\infty} \sum_{i=1}^{N} a_{i}\left\{\delta\left(f-f_{i}^{\prime}\right)+\delta\left(f+f_{i}^{\prime}\right)\right\} \\
& \sum_{j=1}^{M} b_{j}\left\{\delta\left(f-f_{j}^{\prime \prime}\right)+\delta\left(f+f_{j}^{\prime \prime}\right)\right\} d f_{1} \\
= & \sum_{i=1}^{N} \sum_{j=1}^{M} a_{i} b_{\jmath}\left\{\delta\left(f-f_{i}^{\prime}-f_{j}^{\prime \prime}\right)+\delta\left(f-f_{J}^{\prime \prime}+f_{i}^{\prime}\right)\right. \\
& \left.+\delta\left(f-f_{i}^{\prime}+f_{j}^{\prime \prime}\right)+\delta\left(f+f_{i}^{\prime}+f_{j}^{\prime \prime}\right)\right\}
\end{aligned}
$$

上式から，畳込みによるスペクトルの広がりは $F(f)$ と $G(f)$ のそれぞれの最大值の和 $F_{\max }(f)+G_{\max }(f)$ を超えることは ない, 以上の議論より, 以下の定理が成り立つ. 


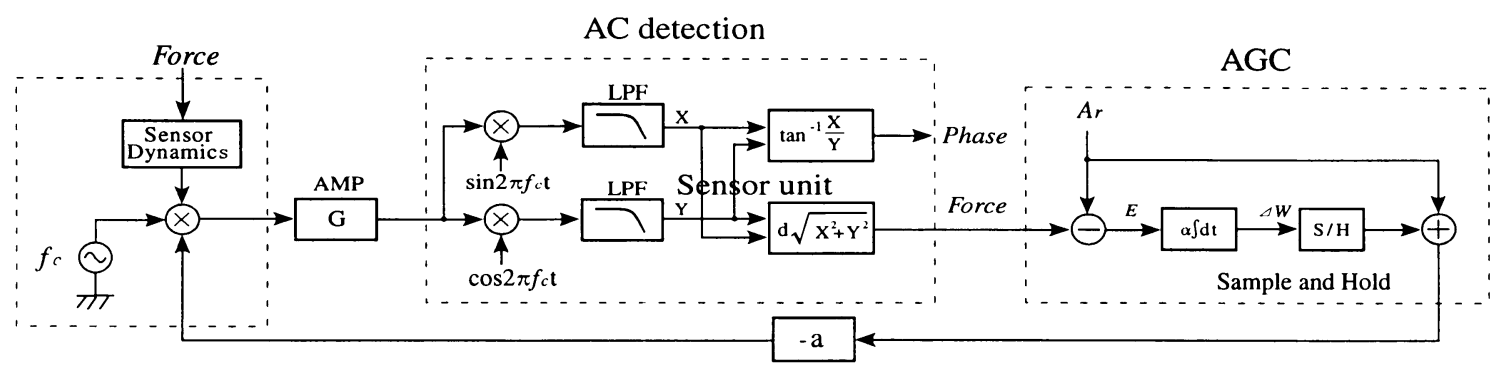

Fig. 4 A feedback loop for the tactile sensor with AGC

定理 1 AGC機能を備えた触覚センサが適切に動作するた めの十分条件は下記で与えられる。

$$
F_{\text {max }}(f)+G_{\max }(f)<f_{\text {cut }}<f_{c}
$$

(証明) 式 (13) より, $F(f) * G(f)$ の带域 range $\{F(f) * G(f)\}$ は次の関係を持つ。

$$
\operatorname{range}\{F(f) * G(f)\} \leq F_{\max }(f)+G_{\text {max }}(f)
$$

接触力 $f(t)$ とゲイン $g(t)$ の積が第 3 章の接触力とみなすことが できるから，式 (6) の $f_{\text {input }}$ の代わりに range $\{F(f) * G(f)\}$ をと机ばよい。よって，式（15）を考虑す机ば，式（14）が十 分条件となることは自明.

次に, Fig.4に示すようにサンプルホールドでゲインを更新す る場合を考えてみよう。この場合，ゲイン $g(t)$ は，無限大の調 波数を含むことになる。ここで，仮にゲイン $g(t)$ を Fig. 5 (a) のように変化させた場合のスペクトル $G(f)$ を考えるこににす る. Fig. 5 (a)は Fig. 5 (b) と Fig. 5 (c)の時間領域における積で 表現できるので，周波数領域の胃込みとなる。ここでは，ゲイ ン $g(t)$ を複素フーリ工級数で展開する.

$$
\begin{aligned}
V(t)= & A(t) \sin \left(2 \pi f_{c} t\right) \times \sum_{n=-\infty}^{\infty} \frac{\tau \sin \left(n \pi \frac{\tau}{T}\right)}{n \pi} e^{j n \omega t} \\
= & \frac{\tau A(t)}{T} \sin \left(2 \pi f_{c} t\right)+2 A(t) \frac{\sin \left(\frac{\pi \tau}{T}\right)}{\pi} \sin \left(2 \pi f_{c} t\right) \cos (\omega t) \\
& +2 A(t)\left(\frac{\sin \left(\frac{2 \pi \tau}{T}\right)}{2 \pi}\right) \sin \left(2 \pi f_{c} t\right) \cos (2 \omega t)+\cdots
\end{aligned}
$$

ただし， $\omega=2 \pi / T, \tau=T-T_{1}$ とする。この級数よりゲイン $g(t)$ のスペクトル $G(f)$ は, 無限の周波数を含むことが分かる. したがって, $G(f) * F(f)$ のスペクトルの広がりは, 無限大とな るために定理 1 の不等式（14）を満足しなくなる．よってステッ プ状にゲインを変えると，振幅変調を正しく行えないことにな る。ただし，こ机はすべてのデー夕を使用するために無限のス ペクトルが発生するのであって，ゲインを変えた前後のデー夕 を使用しなけ机ば無限のスペクトルは出てこない．ゲインを更 新した後，時間 $T_{w}$, だけ待って計測を行えば，検出可能な最大 周波数は低くなるものの許容䛊差範㜀内で接触力の検出を行う ことができる．この $T_{w}$ は，Fig. 4 のループ内でアンプを理想 特性であるとし，遅机の要素が検波の LPF とすると，次の定理 2 によって決定することができる。

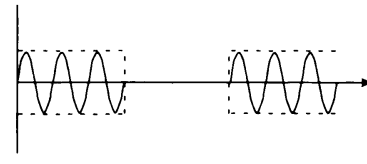

(a) $\mathrm{A} \times \mathrm{B}$

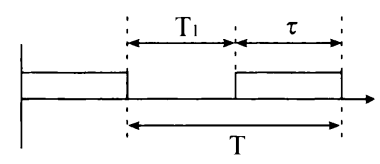

(b) $\mathrm{A}$

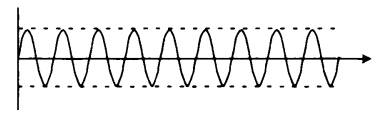

(c) B

Fig. 5 An example of the sine wave with bursting

定理 $2 H(s), p, L T^{-1}$ をそれぞれ LPF の伝達関数，設 計者が沈めるパラメー夕，逆ラプラス変換とすると，

$$
L T^{-1}\left\{H(s) \frac{1}{s}\right\}(t) \geq \frac{100-p}{100}
$$

を満たす $t$ の最小值を $T_{u}$ とする。このとき，ゲインをステッ プ状に変化させた後， $T_{w}$ 時間経過したときの接触力は定常状 態に対して䛊差 $p \%$ の精度が保㹬さ机る。

(証明) $H(s)$ のステップ応答は, $L T^{-1}\left\{H(s) \frac{1}{s}\right\}$ で求めるこ とができる。この出力が定常状態の $100-p \%$ に到達する条件 は, 式（17）でjえら机ることは自明.

ただし，フィルタの種類によっては $T_{u}$ 時間後から次のゲイ ン更新周期までのデータが，リンキングやオーバーシュートに よって $p \%$ の精度を保証できないことに注意されたい， $T_{w}$ 以 降に対して誤差 $p \%$ の精度を保証するためには，直線位相特性 を有するフィル夕を用い机ばよい。

式 (17) で求めた $T_{w}$ を使えば, $\mathrm{AGC}$ の利得更新周期 $T_{A G C}$ は次のように表せる。

$$
T_{A G C}>T_{w}
$$

この関係式より，AGCを行ったときの実質的なセンシングのサ ンプリング周波数は $1 / T_{A G C}$ となり，七ンサに印加できる最大 周波数は次のようになる。

$$
T_{\text {input }}<\frac{1}{2 T_{A G C}}
$$

ただし，1/T AGC は $f_{\text {cut }}$ と関倸を持つ。

\section{5. 実験}

\section{1 実験装置}

試作した触覚センサを Fig. 6 に示す。この触覚センサは，ス 


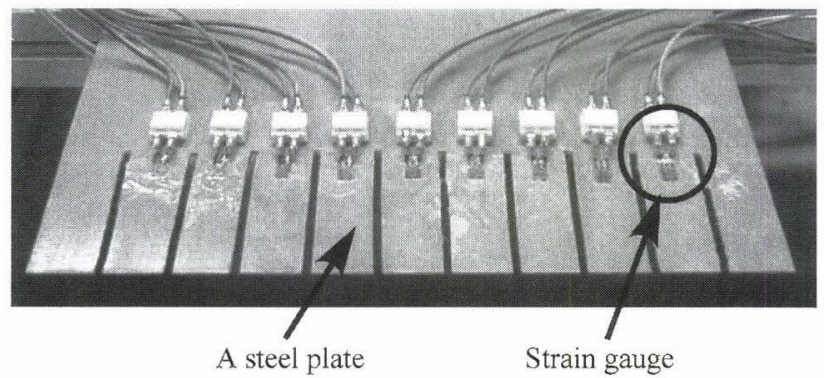

Fig. 6 An overview of the tactile sensor

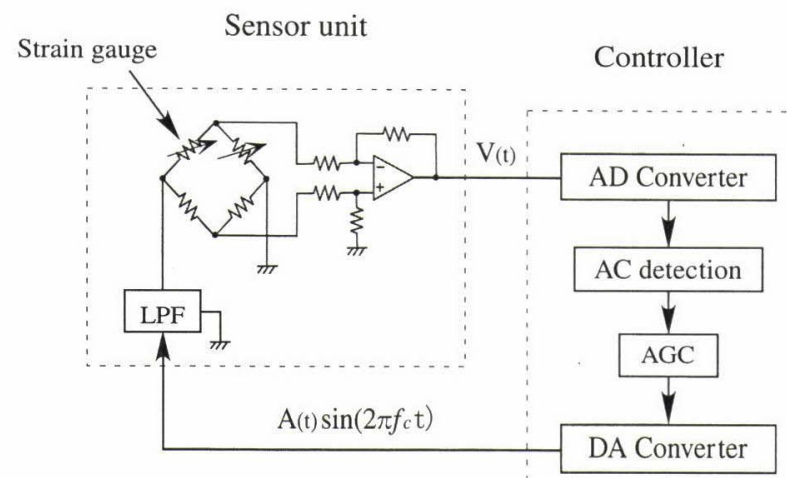

Fig. 7 Test circuit of tactile sensor

チール板に $1[\mathrm{~mm}]$ の切れ目を人れ, 歪ゲージを貼り付けたシ ンプルな機構になっている。触覚センサの両面には，一つの計 測点に対して二つの歪ゲージを貼り付けており，ブリッジを組 んで温度補償を行っている。各計測点は，Fig. 7 に示す回路構 成を基本としており，複数計測点の場合は，周波数多重，また は時分割等で構成することができる．Fig.7において，DA変 換器からソフトウェアによって正弦波を作り出し，30[kHz]で アナログ出力を更新してある。ブリッジ電源の前にLPFを置く ことで带域制限を行うことができるが，本実験装置では，LPF を配置せずに実験を行った。計測点からの出力はインスッルメ ンテーション・アンプでおよそ 1,000 倍に増幅し, $5[\mathrm{kHz}]$ でサ ンプリングを行った。検波で用いるデジタル LPFは，カットオ フ周波数 $50[\mathrm{~Hz}]$ の二次ベッセル特性で設計した。実験では，定 理 2 で示した待ち時間 $T_{w}$ 以外に, 正弦波をDA变換器で作り 出したため, ゲイン更新に伴いDA 変換器のメモり書換え時間 $T_{1}$ が余計にかかっている。したがって，ゲイン更新周期 $T$ を $250[\mathrm{~ms}]$ とした.

\section{2 実験結果・考察}

Fig. 8 は，AGC を行わなかったときの実験結果である. Fig. 8 (a) は差動アンプからの出力信号で, Fig. 8 (b)は, DA 変 換器からの印加電圧である. Fig. 8 (a)において, $t=0.7[\mathrm{~s}]$ 瑷に $\mathrm{AD}$ 変換器が飽和している様子がうかがえる. Fig. 9は, 単一計 測点に対してAGC 在行った場合の実験結果である。Fig.9(a) は, 差動アンプの出力信号で, Fig. 9 (b) は, DA 変換器からの 印加電圧である。 センサのゲインが接触力に応じて小さくなっ ていく様子がうかがえる。ただし，Fig.9に拈いて $T_{A G C ， T_{1}}$

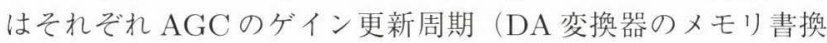

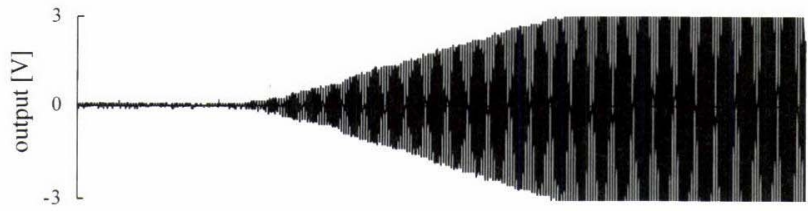

(a) Sensor output

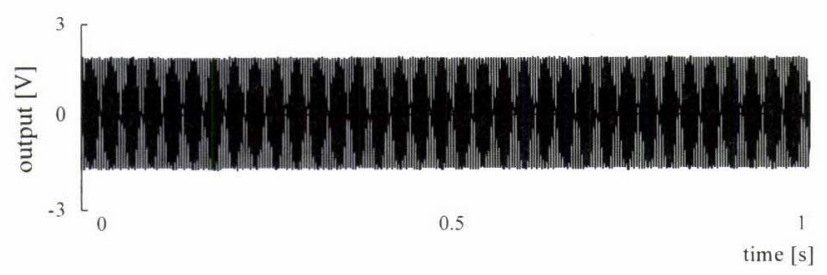

(b) D/A output

Fig. 8 Experimental results without AGC

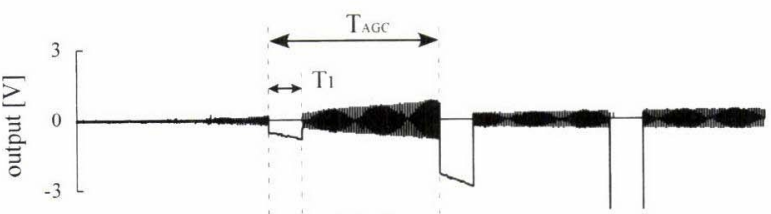

(a) Sensor output

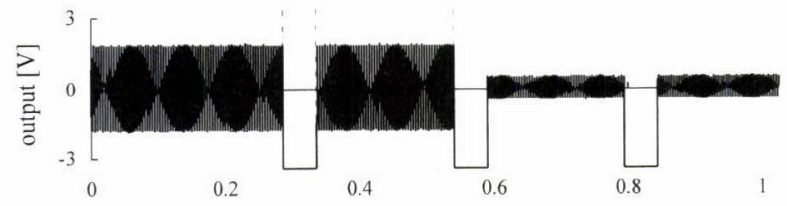

(b) $\mathrm{D} / \mathrm{A}$ output

time $[\mathrm{s}]$

Fig. 9 Experimental results with AGC

え時間を含む)，DA 変換器のメモリ書換え時間である。実験で は, $T_{A G C}=250[\mathrm{~ms}]$ としたため式 (19) より入力の最大周波 数は $2[\mathrm{~Hz}]$ に限定された。ただし，付録のFig. 11，Fig. 12 に示 すような回路で AGC を構成すれば，ゲインのスイッチング周 波数を十分高くとることができる。

ここで，実際にセンサを設計する上での定理 1，2 利用上の注 意点についてまとめてみよう。まず，定理 1 に㧍いて $f_{c}$ はど の程度まで高く設定できるのだろうか。一般に，交流電源方式 の歪ゲージ式のセンサは浮遊容量等の問題から搬送波の周波数 $f_{c}$ を数 $[\mathrm{kHz}]$ 程度までしかとることができない. したがって， $\mathrm{AGC}$ を行わなくても式（6）の関係より，動歪の測定には上限 が出てくる。この上限の範用に限って定理 1 が成り立つことに 注意されたい.

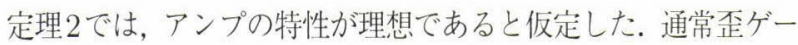
ジの出力は数 $\mu$ 数 $[\mathrm{mV}]$ と微弱なためアンプで $1,000 \sim 10,000$ 倍に増幅しなければならない。したがって，実際問題としてア ンプの周波数特性をまったく無視する訳にはいかない。例えば アンプの性能指標の一つである利得帯域幅積（gain-bandwidth product：GB積） $f_{G B}$ は，次式で与えられる.

$$
f_{G B} \simeq A_{D C} \times f_{c u t}^{\prime}
$$

ただし $A_{D C}, f_{\text {cut }}^{\prime}$ はそれぞれ, 直流増幅度, 遮断周波数と する。汎用オペアンプの $f_{G B}$ はふつう数 $[\mathrm{MHz}]$ 程度なので 


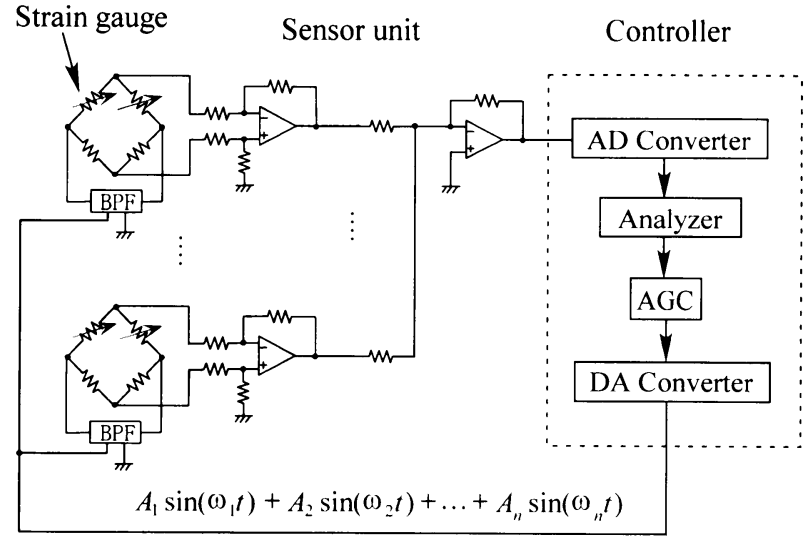

Fig. 10 Sensor system with multiple units

$f_{G B}=3[\mathrm{MHz}]$ とすると, $A_{D C}$ を 1,000 - 10,000 とした場合, 300 ３,000 [Hz] の信号しかき机いに増幅することができない. この点を, 定理 2 と兼权合せて注意しなけ机ばならない.

\section{6. 複数計測点への応用}

ここでは複数のセンサユニットに本手法を応用する方法につ いて考察する．特に，少配線化を考慮してセンサユニットからの アナログ信号を1本の信号線に多重化する力法を考える. 多重化 の方法は, 時分割多重方式と周波数分割多重方式が考えられる. 時分割多重方式は, 各計測点の信号を一定時間間隔で転送する 方式であり，周波数分割多重方式は各計測点ごとに周波数带域 を割り当てて転送する方式である。本研究ではブリッジ電源に 交流電源を採用したので, 数チャネルの計測点であれば周波数 分割多重方式で同時計測を容易に行うことができる.Fig. $10 に$ 複数チャネルの触覚センサの一例の構成を示す。この同時計測, 同時ゲイン調整における信号の流れは次に示すとおりである. まず,コントローラ内の DA 变換器から周波数の異なる正弦波 の和をセンサユニットに出力する. 次に各計測点の前段に置か れたBand Pass Filter（BPF）によってあらかじめ決められた 周波数の単一正弦波だけが，各ブリッジ回路に加えられる。し たがって各計測点のゲイン調整は, それぞれ対応する正弦波の 振幅を変えることで行うことができる. 各ブリッジからの出力 信号は加算回路で多重化され, 単一の $\mathrm{AD}$ 変換器でコントロー ラ内に取り込まれる。理論上はリング変調器などを使って周波 数変換を行えば, 1 計測点当たり $500[\mathrm{~Hz}]$ の带域を占有する場 合， DC 100 [MHz] の信号を転送できるケーブルなら 20 万点 程度の計測点を作ることも可能である。本論文では AGC 機能を 備えたセンサシステムの設計条件を示すという立場をとり，多 重化については比較的谷易に対応できるというレベルにとどめ ておく.

\section{7. を め}

本論文では AGC 機能を備えた歪ゲージ式触覚センサを提案 し, 試作実験を行った。この研究のポイントをまとめると以下 のようになる。

（1）触覚セン耒のダイナミックレンジを広くすることができる
AGCを提案した。

（2） AGC 機能を備えた触覚センサが適切に動作するための条 件を二つの定理としてまとめた。

（3）実験システムを提案し, 定理 2 に基ついて計測方法につい て实験的に考察した。

\section{参 考 文 献}

[1] H.A. Ernst: "MH-1-A Computer-Operated Mechanical Hand," Proc. of the AFIPS Spring Joint Computer Conference, vol.21, pp.39-51, 1962.

[2] R.D. Howe and M.R. Cutkosky: 'Touch Sensing for Robotic Manipulation and Recognition,' The Robotics Review 2. Cambridge, MA: MIT Press, pp.55-112, 1992.

[ 3 ] H.R. Nicholls and M.H. Lee: "A Survey of Robot Tactile Sensing Technology," Int. J. of Robotics Res., vol.8, no.3, pp.3-30, 1989.

[4] R.S. Fearing: "Tactile Sensing Mechanism," Int. J. of Robotics Res, vol.9, no.3, pp.3-23, 1990.

[5] M. Shimojo, M. Ishikawa, and K. Kanaya: "A Flexible High Resolution Tactile Imager with Video Signal Output," IEEE ICRA, pp.348-391, 1991.

[6 ] I.J. Busch-Vishniac: "Spatially Distributed Transducers. Part II, Augmented Transmission Line Models," Trans ASME, vol.112, pp.381-390, 1990.

[ 7 ] Y. Yamada. K. Shin, N. Tsuchida and M. Komai: "A Tactile Sensor System for Universal joint Sections of Manipulator," IEEE Trans. of Robotics and Automation, vol.9, pp.512-517, 1993.

[8] M. Nilsson: "Tactile Sensors and Other Distributed Sensors with Minimal Wiring Complexity," IEEE/ASME Trans. on Mechatronics, vol.5, no.3, pp.253-257, 2000.

[9] H. Shinoda and H. Oasa: "Wireless Tactile Sensing Element Using Stress-Sensitive Resonator," IEEE/ASME Trans. on Mechatronics, vol.5, no.3, pp.258-265, 2000.

[10] M. Shimojo, M. Shinohara and Y. Fukui: "Human Shape Recognition Performance for 3-D Tactile Display," IEEE Trans. on Systems, Man, and Cybernetics, Part A, vol.29, no.6. pp.637-644, 1999.

[11] J.S. Son and R.D. Howe: "Tactile Sensing and Stiffness Control with Multifingered Hands," Proc. of the 1996 IEEE Int. Conf. Robotics and Automation, vol.4, pp.3228-3233, 1996.

[12] H. Maekawa, K. Tanie, K. Komoriya and M. Kaneko: "Development of a Finger-Shaped Tactile Sensor and its Evaluation by Active Touch," Proc. of the 1992 IEEE Int. Conf. Robotics and Automation, vol.2, pp.1327-1334, 1992.

[13] M. Ueda, et al.: "Tactile Sensors for Industrial Robot to Detect Slip," Proc. of the 2nd ISIR, IIT Research Institute, Chicago. pp.63-76, 1972.

[14] T. Maeno, K. Kobayashi and N. Yamazaki: "Sensing Mechanisms of The Partial Incipient Slip at the Surface of Cylindrical Fingers During the Precision Grip," Proc. of 1997 Summer Bioengineering Conference, pp.117-118, 1997.

[15] R.D. Howe and M.R. Cutkosky: "Sensing Skin Acceleration for Slip and Texture Perception," Proc. of the 1989 IEEE Int Conf. Robotics and Automation, pp.145-150, 1989.

[16] R.D. Howe and M.R. Cutkosky: 'Touch Sensing for Robotic Manipulation and Recognition; The Robotics Review 2. O. Khatib, et al., eds.. MIT Press, pp.55-112, 1992.

[17] R.A. Russell: "Closing the Sensor-computer-robot Control Loop," Robotics Age, vol.6, no.4, pp.15-20, 1984.

\section{付録 A. AGC の回路構成}

式（1）において出力電圧 $V(t)$ を変化させることができる変 


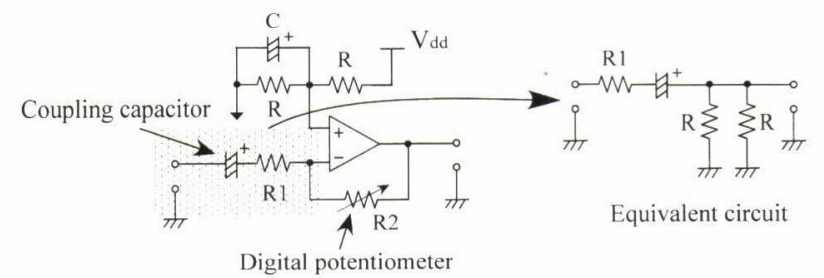

Fig. 11 An example of AGC amplifier circit

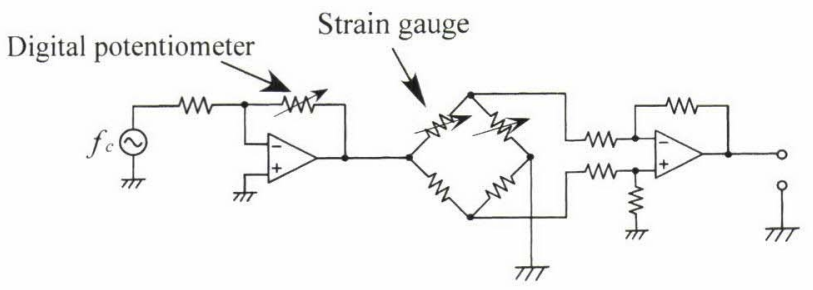

Fig. 12 An example of the oscillation circuit

数は, $G$ と $A$ のつあることが分かる.つまり, Fig. 1(a)のよ うにブリッジ電源の電压振幅 $A$ は一定の状態で差動アンプのゲ イン $G$ を変える方法と, Fig. 1 (b)のように差動アンプのゲイ ン $G$ は一定のままでブリッジ電源の電圧振幅 $A$ を変える方法 である.Fig.11にFig. 1 (a)のゲイン可変アンプの一例を示す.
これは，CPU等から制御可能なディジタルポテンショメータを OPアンプの㷌還抵抗とした回路である. Fig. 1 (a)がFig. 1 (b) に比べて優れている点は, ブリッジの零点の変動が少ないこと である。零点の変動とは,ブリッジのバランスをとってもしば らくするとそのバランスが崩れる現象である。これは, 歪ゲー ジに流す電流が多い場合にジュール熱による発熱と放熱によっ て抵抗值が変わることが要因である。したがって, 歪ゲージに 流す電流は極力少なくしなけ机ばならないことから，ブリッジ 電源を小さく一定に固定し，後段のアンプでゲイン調節を行う Fig. 1 (a)の方が零点の変動に対して強いことになる. Fig. 12 にFig. 1 (b) の回路構成の一例を示す.Fig. 12 は, 発振回路を

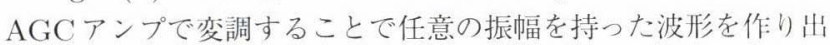
す回路である.Fig. 1 (b)がFig. 1 (a)に比べ優れている点は, 差 動アンプで増幅する前にノイズが進入した場合, Fig. 1 (a)では $\mathrm{S} / \mathrm{N}$ 比が改善できないのに対し，Fig. 1 (b)はS/N比を改善する ことができる点である。これは，Fig.1(a)の場合だとノイズま で一緒に増幅するので $\mathrm{S} / \mathrm{N}$ 比が変わらないのに対し, Fig. 1 (b) はブリッジ電源を大きくして増幅するので信号の強度を大きく することができ，その結果 $\mathrm{S} / \mathrm{N}$ 比を大きくすることができるか らである。

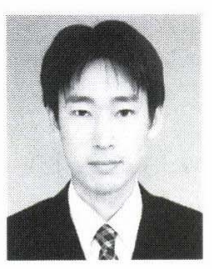

堀江竜太 (Ryuta Horie)

1977 年 11 月 11 日坐. 2001 年広島大学工学部第 2 類 (電気系) 卒業. 2001 年広島大学大学院工学研 究科人学. 現在, 修士課程に在学中.

(日本ロボット学会学生会員)

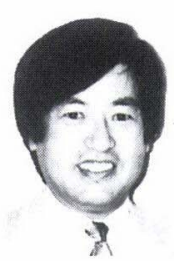

金子 真 (Makoto Kaneko)

1954 年 1 月 18 日生. 1981年東京大学工学系研究科 博士:棵程卒業. 工学博士：通産省工業技術院機械技 術研究所, 九州工業大学助教授を経て 1994 年より 広島大学教授，アクティブセンシングや把握戦略の 研究に興味を持つ。日本機械学会奨励賞 (1983年), 日本ロボット学会論文賞(1994年), 計測白動制御 学会論文賞（1996年，2002 年)，Humboldt Research Award (1997 年), IEEE ICRA The Best Manipulation Paper Award (2000年), 日本機械学会ロボメカ部門功績賞 (2000年), IEEE ISATP The Outstanding Paper Award（2001 年）を受賞.

(日本ロボット学会正会員) 